Science Life

\title{
NOVEL FOODS: REGULATION, HEALTH AND SAFETY CONSIDERATIONS
}

\author{
Livia Simon Sarkadi* and Veronika Gál ${ }^{\star *}$
}

* Applied Biotechnology and Food Science, Budapest University of Technology and Economics,
H-1111 Budapest Mūegyetem rkp. 3., HUNGARY; sarkadi@mail.bme.hu
**National Food Chain Safety Office Directorate for Food Safety Risk Assessment, H-1143 Budapest Tábornok u. 2., HUNGARY;
galv@ nebih.gov.hu

\begin{abstract}
Under the Novel Food Regulation (258/97/EC), a novel food is defined as a food or food ingredient that does not have a significant history of consumption within the European Union prior to 15 May 1997. Novel foods are required to undergo a pre-market safety assessment and must be authorised before they can legally be marketed in the EU. A proposal to revise and update the EU Novel Food Regulation was published in 2008. This proposed a definition for nanomaterials, a centralised and faster authorisation procedure and specific measures for traditional foods from third countries. As a result of disagreement on the inclusion of foods from cloned animals, the European Parliament and Council were unable to reach agreement on the new regulation before the deadline of 30 March 2011. New discussions on the updated Regulation are expected to take place in 2012. So far 66 novel foods and food ingredients have been authorised for use in the EU. The most popular products are Noni juice (juice of the fruits of Morinda citrifolia) and phytosterols in a number of foodstuffs.
\end{abstract}

Key words: novel food, novel food ingredient, novel food regulation, food safety.

\section{REGULATION}

Definition of novel food. A novel food is a food or food ingredient that does not have a significant history of consumption within the European Union before 15 May 1997, and which falls under the following categories:

- foods and food ingredients with a new or intentionally modified primary molecular structure;

- foods and food ingredients consisting of or isolated from microorganisms, fungi or algae;

- foods and food ingredients consisting of or isolated from plants and food ingredients isolated from animals, except for foods and food ingredients obtained by traditional propagating or breeding practices and having a history of safe food use;

- foods and food ingredients to which a production process not currently used has been applied, where that process gives rise to significant changes in the composition or structure of the foods or food ingredients, which affect their nutritional value, metabolism or level of undesirable substances.

These rules were applicable also to foods containing or consisting of a genetically modified organism (GMO), until 2003 when the GMO Regulation (1829/2003/EC) came into force. Furthermore, if foods and/or food ingredients were used exclusively in food supplements, new uses in other foods required authorisation under the Novel Food Regulation e.g. food fortification required authorisation.

The Regulation does not apply to foods and ingredients for which an approval exists:

- food additives falling within the scope of Council Directive 89/107/EEC;

- flavourings for use in foodstuffs, falling within the scope of Council Directive 88/388/EEC;

- extraction solvents used in the production of foodstuffs, falling within the scope of Council Directive 88/344/ EEC;

- food enzymes falling within the scope of Regulation (EC) No 1332/2008.

Authorisation procedure. Before novel foods can be placed on the market, they must go through an authorisation procedure.

There are two possible routes for authorisation under the Novel Food Regulation:

- full application,

- simplified application. 
It is important to note that there is a non-exhaustive list ("Novel Food Catalogue") containing information exchanged among Member States and the Commission, to find out whether a product falls within the scope of the Novel Food Regulation. This catalogue is a living database, but has no legal basis. It lists products of plant and animal origin and other substances subject to the Novel Food Regulation, after EU countries and the Commission has discussed and agreed with their "novel" status.

Full application. If a food is found to be considered novel in compliance with the $258 / 97 / \mathrm{EC}$, then it shall be subject to a safety assessment. The food or food ingredient manufacturer or distributor may request authorisation from the relevant committee in Brussels through the competent authority of the country, where it was first proposed to market the product. The applicant must provide a substantial set of information to the authority, with which it can prove that the substance is safe. The 97/618/EC Commission Recommendation specifies exactly which data, information, and in what form must be included in the documentation submitted by the applicant to ensure that the safety assessment can be carried out.

The first assessment of the safety of a novel food is conducted in the Member State in which the product is to be first placed on the market. The competent authority in the relevant Member State draws up the initial assessment report within 90 days. The summary of the application dossier and the initial assessment are circulated by the Commission to all the Member States for comments (which may include reasoned objections) for a period of 60 days. If the initial assessment is favourable and no reasoned objections are raised, then the applicant is notified by the Member State that the product can be marketed.

Where a reasoned objection is raised or further assessment is requested, the application is transferred to the European Food Safety Authority (EFSA) for an additional assessment. The EFSA safety assessment is considered by Member States at the Standing Committee for the Food Chain and Animal Health (SCFCAH). Where a qualified majority vote (QMV) is achieved, the application is authorised by Commission Decision. Where a QMV is not achieved, the application is transferred to the European Council of Ministers.

Finally, all decisions are published in the Official Journal of the European Union. The full authorisation procedure of novel food is illustrated by Figure 1.

Simplified application - notification. Regulation (EC) No. 258/97 on novel foods and novel food ingredients provides a simplified route for manufacturers to bring certain novel products to the market, by making a notification.

This procedure applies only to:

(a) foods and food ingredients consisting of or isolated from micro-organisms, fungi or algae; and (b) foods and food ingredients consisting of or isolated from plants and food ingredients isolated from animals (except for foods and food ingredients obtained by traditional propagating or breeding practices and having a history of safe food use),

and the product in question must be shown to be "substantially equivalent" to an existing food or food ingredient as regards:

- its composition (such as the source organism and preparation method),

- its nutritional value,

- its metabolism,

- its intended use (such as a food ingredient or supplement) and

- the level of undesirable substances (such as contaminants, mycotoxins and allergens).

In practice each notification requires a suitable opinion from a competent authority in one of the Member States, confirming that the product meets these criteria. After the company obtains an opinion on equivalence from an EU Member State, it then can submit a notification directly to the European Commission.

The products covered by the scope of the Novel Food Regulation may only be placed on the market if, within the framework of the authorisation procedure or notification, it has been proved that they do not

(a) present a danger for the consumer,

(b) mislead the consumer,

(c) differ from the convention products that they are intended to replace to such an extent that their normal consumption would be nutritionally disadvantageous for the consumer.

Revision of Novel Food Regulation. On 14 January 2008, the European Commission published a proposal to revise the Novel Food Regulation with a view to simplifying the regulatory process, therefore, reducing the administrative burden and improving the competitiveness of the European food industry.

The key elements of the proposal were:

- centralising the authorisation procedure for novel foods,

- developing a simplified safety assessment system for traditional food from third countries,

- clarifying of the definition of novel food (nanotechnology, animal cloning),

- updating the scope of the Novel Food Regulation in relation to parallel legislation on specific categories of foods, 


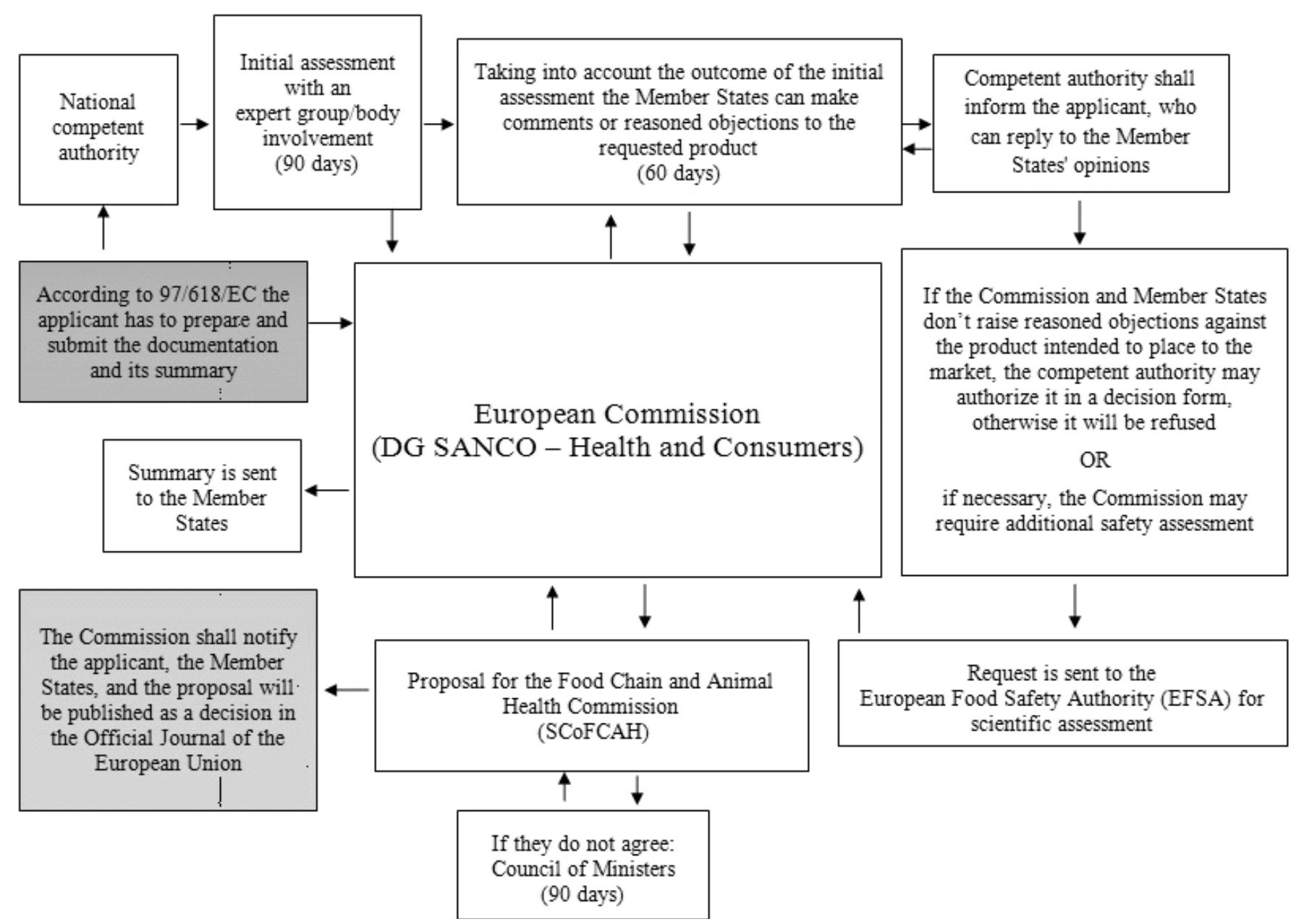

Fig. 1. Scheme of the novel food authorisation procedure.

- providing a degree of protection for innovative food.

As a result of disagreement on the inclusion of foods from cloned animals, the European Parliament (EP) and Council were unable to reach agreement on the new regulation before the deadline of 30 March 2011.

Regarding the revision of Regulation (EC) 258/97 on Novel Food:

- the Commission has the intention to adopt two separate legislative proposals on

1) novel foods except animal cloning, and

2) animal cloning for food production.

- The Novel Food legislative proposal can still be adopted in 2012, but this depends on if the EP can commit not to re-introduce amendments on cloning in the Novel Food text. Otherwise the Commission will introduce the two texts at the same time in 2013.

Finally, a point on nanomaterials: the Novel Food legislative proposal will cover the nanomaterials explicitly (they are covered currently by the Novel Food category defined by "food obtained from new production processes" but not explicitly). A regulatory definition of "nanomaterial" based on the Commission Recommendation for a nanomaterial definition (2011/696/EU) is expected to be introduced, as well as the requirement for a systematic assessment and approval of all nanomaterials under the Novel Food Regulation (except for nano additives for which there are specific requirements in the EU food additives Regulation). The labelling requirement for nanomaterials in food products has recently been adopted within the framework of the EU Regulation on Food Information to Consumers and is applicable to all nano food ingredients whatever their status (novel food or food additives). It enters into application by the end of 2014.

\section{HEALTH CONSIDERATION OF NOVEL FOODS}

The purpose of a risk assessment for a novel food is to evaluate its potential impact on public health and safety status. During the evaluation of the public health and safety of a novel food or novel food ingredient, a variety of toxicological and nutritional issues have to be considered together with information on its chemistry and the amount of people expected to eat it. 
There have been a number of products launched as a result of food or food ingredients authorised under the Novel Food Regulation. Some examples of recently approved novel foods and food ingredients are listed in Table 1.

Table 1

EXAMPLES OF AUTHORISED NOVEL FOOD INGREDIENTS

\begin{tabular}{|c|c|}
\hline Decision No. & Novel food ingredient \\
\hline 2011/882/EU & a novel chewing gum base as a novel food ingredient \\
\hline 2011/762/EU & yeast beta-glucans as a novel food ingredient \\
\hline 2011/761/EU & flavonoids from Glycyrrhiza glabra L. \\
\hline 2011/513/EU & phosphatidylserine from soya phospholipids \\
\hline 2011/497/EU & fermented black bean extract \\
\hline 2011/494/EU & phosphated maize starch as a novel food ingredient \\
\hline 2011/320/EU & chromium picolinate \\
\hline $2011 / 76 / \mathrm{EU}$ & chitin-glucan from Aspergillus niger \\
\hline 2011/73/EU & $\begin{array}{l}\text { mycelial extract from Lentinula edodes (Shiitake mush- } \\
\text { room) }\end{array}$ \\
\hline 2010/715/EU & ferrous ammonium phosphate \\
\hline 2010/331/EU & ferric sodium EDTA \\
\hline 2010/228/EU & puree and concentrate of the fruits of Morinda citrifolia \\
\hline 2009/827/EU & Chia seed (Salvia hispanica) \\
\hline 2009/826/EU & leaf extract from Lucerne (Medicago sativa) \\
\hline 2009/778/EU & algal oil from the micro-algae Schizochytrium \\
\hline 2009/777/EU & algal oil from the micro-algae Ulkenia \\
\hline 2009/752/EU & lipid extract from Antarctic Krill Euphausia superba \\
\hline 2009/362/EU & lycopene \\
\hline 2009/365/EU & lycopene from Blakeslea trispora \\
\hline 2009/355/EU & lycopene oleoresin from tomatoes \\
\hline 2009/344/ EU & Ice Structuring Protein type III HPLC 12 \\
\hline 2009/345/EU & Vitamin K2 (menaquinone) from Bacillus subtilis natto \\
\hline
\end{tabular}

The most popular product is Noni juice (juice of the fruits of Morinda citrifolia). Morinda citrifolia's native range extends through Southeast Asia and Australasia, and the species is now cultivated throughout the tropics and widely naturalised. The main micronutrients of $M$. citrifolia pulp powder include vitamin $\mathrm{C}$, niacin (vitamin $\mathrm{B}_{3}$ ), iron and potassium. M. citrifolia fruit contains a number of phytochemicals, including lignans, oligo- and polysaccharides, flavonoids, iridoids, fatty acids, scopoletin, catechin, betasitosterol, damnacanthal, and alkaloids. In 2009, the EFSA Panel on Dietetic Products, Nutrition and Allergies concluded that Morinda citrifolia (Noni) fruit puree and concentrate as novel food ingredients under the specified conditions are considered safe for the general population. It is mentioned however, that the increasing number of case reports might indicate that some individuals have a particular sensitivity for hepatotoxic effects to noni fruit products.

The failure to agree on a new Novel Food Regulation means that exotic fruit and vegetables, which have a long history of safe use outside of the European Union, fall within the definition of a novel food. As a consequence, each of these food products must undergo a safety assessment prior to being marketed. Recent examples of products challenged by the Novel Food Regulation include the vitamin C-rich Ama- zonian fruit, commonly known as camu camu (Myrciaria dubia), baobab (Adansonia digitata) from Southern Africa, and the Andean root yacon (Smallanthus sonchifolius), all of which are established components of human diets, albeit outside of Europe.

There is a need for an updated definition of a novel food to clarify new technologies not currently being used in the food chain, such as nanotechnology and animal cloning. The special characteristics and properties of engineered nanomaterials, such as the small size, surface reactivity and translocation across biological membranes as well as their interactions with the surrounding matrix and unexpected effects resulting from this may require generation of specific data for risk assessment purposes. There are at present difficulties detecting engineered nanomaterials in food and feed matrices and consequently risk assessment is complicated. Cloning is widely used in horticulture, and some foods such as potatoes, bananas and grapes are derived from clones. Clones of cattle and other farm animals can be produced using a technique known as somatic cell nuclear transfer. Since 1997, food products from cloned animals have been subject to a pre-market authorisation under the Novel Food Regulation (258/97/EC), but no application has been submitted so far, and therefore, no authorisation granted.

\section{SAFETY CONSIDERATION OF NOVEL FOODS}

In order to protect public health, it is necessary that novel foods and novel food ingredients are subject to a single safety assessment through a Union procedure before they are placed on the market within the Union.

The European Commission published criteria for safety assessment in its recommendation (97/618/EC) concerning the scientific aspects and the format of the information required in applications for authorisation for novel foods and food ingredients.

The key elements for the safety assessment of novel foods are:

- history of use,

- dietary exposure,

- detail of novel process,

- genetic modification considerations,

- nutritional considerations,

- toxicology considerations,

- allergenicity considerations,

- chemical considerations,

- microbiological considerations.

The European Food Safety Authority (EFSA) regularly publishes its opinion on the potential risks arising from novel 
foods and food ingredients and organises scientific colloquium to discuss specific topics on Novel Foods.

In November 2009, the EFSA organised a Scientific Colloquium (EFSA 13th Scientific Colloquium, 19-20 November 2009, Amsterdam, The Netherlands) with international experts to discuss scientific information needed for applications on novel foods and novel food ingredients submitted for authorisation in the European Union. Discussions focused on various aspects in the safety assessment of Novel Foods, such as history of safe use, traditional foods from countries outside the EU, intake assessment, toxicological data requirements and emerging sciences such as nanotechnology.

The main conclusions from the opinions on nanoscience and nanotechnologies in food and feed are:

- the current risk assessment paradigm is appropriate for nanomaterials,

- there are limited data on oral exposure to nanomaterials and any consequent toxicity,

- there are limited methods to characterise, detect, and measure nanomaterials in food/feed.

In May 2011, the European Food Safety Authority published a guidance document for the risk assessment of engineered nanomaterial applications in food and feed. The guidance document is the work of the Authority's Scientific Committee and is the first of its kind to give practical guidance for addressing potential risks arising from applications of nanoscience and nanotechnologies in the food and feed chain. It covers risk assessments for food and feed applications, and includes food additives, enzymes, flavourings, food contact materials, novel foods, feed additives and pesticides. Regarding foods derived from cloned animals, the EFSA will provide an updated opinion by mid 2012.

It might be concluded that the food authorisation procedure based on the Novel Food Regulation (258/97/EC) is unnecessarily expensive and complicated and even from the sci- entific point of view a lot of problems have arisen during the last 15 years. So we can say that there is an urgent need of the Commission, of the Member States and the whole food industry and commerce, to launch a revised version of this Regulation.

\section{LITERATURE}

BfR (Bundesinstitut für Risikobewertung). Health Assessment of Novel Foods

http://www.bfr.bund.de/en/health_assessment_of_novel_foods1809.html.

EFSA (European Food Safety Authority) (2009). Opinion on the safety of Tahitian Noni ${ }^{\circledR}$ Morinda citrifolia (noni) fruit puree and concentrate as a novel food ingredient. The EFSA Journal, 998, 1-16. http://www.efsa.europa.eu/en/efsajournal/doc/998.pdf

EFSA (European Food Safety Authority) (2011). Guidance on the risk assessment of the application of nanoscience and nanotechnologies in the food and feed chain. The EFSA Journal, 9(5), 2140, 1-36. http://www.efsa.europa.eu/en/efsajournal/doc/2140.pdf

EFSA (European Food Safety Authority). Topics A-Z http://www.efsa.europa.eu/en/topics/topic/nanotechnology.htm?wtrl=01

European Commission Health and Consumers. Novel foods and novel food ingredients.

http://ec.europa.eu/food/food/biotechnology/novelfood/index_en.htm

European Commission Health and Consumers. Novel Food Catalogue. http://ec.europa.eu/food/food/biotechnology/novelfood/novel_food_catalogue_en.htm

Food Standards Agency. Novel foods. http://www.food.gov.uk/safereating/novel/

Regulation EC 258/97: Concerning novel foods and food ingredients. OJ $E U, \mathrm{~L} 43,14.2 .1997,1$.

http://eur-lex.europa.eu/LexUriServ/LexUriServ.do?uri=CONSLEG:199 7R0258:20090807:en:PDF

Recommendation EC 97/618: Concerning the scientific aspects and the presentation of information necessary to support applications for the placing on the market of novel foods and novel food ingredients and the preparation of initial assessment reports under Regulation (EC) No. 258/97 http://eur-lex.europa.eu/LexUriServ/LexUriServ.do?uri=OJ:L:1997:253: 0001:0036:EN:PDF

Recommendation EU 2011/696: On the definition of nanomaterial, L 275/38, 20.10.2011

http://eurlex.europa.eu/LexUriServ/LexUriServ.do?uri=OJ:L:2011:275: 0038:0040:en:PDF.

Wikipedia: Morinda citrifolia.

http://en.wikipedia.org/wiki/Morinda_citrifolia

\section{JAUNĀ PĀRTIKA - REGLAMENTĒŠANA, VESELĪBAS UN DROŠUMA APSVĒRUMI}

Rakstā aplūkota ES jaunās pārtikas (tādas pārtikas, kas ES nav bijusi plaši izmantota līdz 1997. gada 15. maijam) regulas pašreizējās prasības un regulas pārskatîšanas un aktualizēšanas process pēc 2008. gada. Izmaiņas saistītas ar nanomateriālu ieviešanu pārtikā un trešo valstu tradicionālās pārtikas ienākšanu ES. Sakarā ar domstarpībām par pārtiku no klonētiem dzīvniekiem pašlaik nav panākta jaunas regulas redakcijas izveide, un diskusija turpinās. Līdz šim izmantošanai ES ir apstiprināti 66 dažādi jaunās pārtikas produkti un to sastāvdalas. 